\title{
Growth, Biomass, and Nitrogen Use Efficiency of Containerized Fraser Fir (Abies fraseri) as Related to Irrigation and Nitrogen Fertilization
}

\author{
Pascal Nzokou ${ }^{1}$ \\ Department of Forestry, Michigan State University, 126 Natural Resources \\ Building, East Lansing, MI 48824 \\ Bert M. Cregg \\ A214 Plant and Soil Sciences, Department of Horticulture, Michigan State \\ University, East Lansing, MI 48824
}

Additional index words. biomass accumulation, biomass partitioning, nutrient concentration, nitrogen use efficiency, nutrient leaching

\begin{abstract}
Growth and nutrient uptake of containerized fraser fir (Abies fraseri) seedlings in response to irrigation and fertilization was investigated for 2 years in a greenhouse experiment. Height and stem diameter growth increased $12 \%$ to $35 \%$ and $4 \%$ to $32 \%$, respectively, with increased irrigation. There was an inverse relationship between irrigation and foliar nitrogen content and no irrigation effect on foliar phosphorus, potassium, magnesium, and manganese. Irrigation increased foliar calcium. Approximately $2.0 \%$ to $4.5 \%$ of applied nitrogen was lost through leaching. Increases in total biomass in high irrigation treatments were caused by higher root and stem biomass. Higher irrigation treatments increased nitrogen use efficiency (NUE) and assimilatory nitrogen use efficiency probably as a result of increase in carbon assimilation efficiency leading to increase in net primary productivity. There was no clear effect on the root weight ratio, but the index nitrogen availability per unit of foliage indicated a higher availability in plants receiving the lowest irrigation. This suggests that under water stress, the decrease in assimilation and NUE may be buffered by an increase in the plant's ability to provide nitrogen and other nutrients to various organs.
\end{abstract}

Fraser fir [Abies fraseri (Pursh) Poir.] is widely planted for Christmas tree production in the midwest and eastern United States. The species has a unique natural distribution, restricted to high elevations in the southern Appalachian Mountains of southwestern Virginia, western North Carolina, and eastern Tennessee, but intensively planted elsewhere in the United States as a result of its desirable attributes (Beck, 1990; Nzokou and Leefers, 2007). Under current field production practices in the Midwest, the crop is intensively managed with regular applications of inorganic fertilizers and irrigation to satisfy its physiological needs.

Water is an important factor for the numerous physiological and biochemical processes controlling plant growth and productivity (Turner and Begg, 1981). The mechanism of response to water shortage involves stomata closure, which restricts $\mathrm{CO}_{2}$ uptake and

\footnotetext{
Received for publication 25 Jan. 2010. Accepted for publication 26 Apr. 2010.

This project was conducted with funding support from the MSU project GREEEN and the Michigan Christmas Tree Association.

In-kind support from Peterson's Riverview Nursery is also acknowledged.

${ }^{1}$ To whom reprint requests should be addressed; e-mail Nzokoupa@msu.edu.
}

subsequently growth (Jamieson et al., 2009). Water availability, uptake, and utilization also affect nutrient availability, solubility, and use. These processes include element concentrations in the soil solution, because of nutrient diffusion and mass flow to the root surface, absorption of the elements by the roots to shoots, and utilization in the photosynthetic process by the foliage (Alam, 1999).

Nitrogen $(\mathrm{N})$ fertilization and uptake is critical for shoot and root growth. Most $\mathrm{N}$ taken up by crops is retained in plant tissues, where it becomes part of the plant structure and is involved in the photosynthesis or in labile storage (Jamieson et al., 2009). During the growing season, $\mathrm{N}$ is reallocated according to sink demands and is mobilized from sources to sink tissues (biochemical cycling). In addition, seasonal $\mathrm{N}$ resorption is a known mechanism for perennial plants to conserve and reuse stored $\mathrm{N}$ that can substantially impact the $\mathrm{N}$ use efficiency (Coleman et al., 2004; Hinesley et al., 1991). Nitrogen shortages lead to reduction of the RuBisCo (ribulose-1, 5-bisphosphate carboxylaxe/oxygenase) in leaves, causing remobilization of $\mathrm{N}$ to other tissues (Grindley, 1997; Jamieson et al., 2009). This ultimately leads to reduction in light interception and use for photosynthesis (Grindley, 1997).

The capacity of plant roots to absorb water and nutrients is affected by water stress
(Alam, 1999). Nutrient uptake tends to decrease under reduced water availability as a result of a decrease in the transpirational rate and subsequent reduction in the nutrient absorption capacity of roots (Alam, 1999; Levitt, 1980). Changes in soil water also affect root permeability and cause disturbance to root metabolism (Gerakis et al., 1975). However, there are conflicting reports in the literature on plant nutrient uptake and utilization under droughty conditions. Tanguilig et al. (1987) reported decreased $\mathrm{N}$ concentration, whereas other references showed high $\mathrm{N}$ levels in plants under stress attributed either to fast accumulation of proline (Singh et al., 1973) or fast accumulation of free amino acids that are not converted into proteins (Barrett and Naylor, 1966). In addition, the slower growth rate of plants under reduced water conditions can prevent the dilution of nutrients within the plant (Alam, 1999). Studies conducted on various agricultural crops also indicated accumulation of phosphorus, magnesium, potassium, and carbon under drought stress (Jenne et al., 1958).

Another important process that affects the availability and uptake of nutrients under well-watered conditions is the leaching of soluble nutrients below the root zone. When plants are irrigated beyond the soil waterholding capacity, soluble forms of $\mathrm{N}$ and other macronutrients will leach from the root zone.

The objective of our study was to determine the growth, nutrient concentration and content, and $\mathrm{N}$ use efficiency of containerized Abies fraseri in response to watering and $\mathrm{N}$ fertilization.

\section{Material and Methods}

Site and materials. This 2-year greenhouse study was conducted at the Tree Research Center (TRC) at Michigan State University. The greenhouse growing season and average high temperatures were 27 and $20{ }^{\circ} \mathrm{C}$, respectively, and the daytime average operating temperature was $25^{\circ} \mathrm{C}$.

Three-year-old (plug+2) fraser fir (Abies fraseri) transplants were potted in 3-gallon cylindrical black plastic containers. The seedlings averaged $9.3 \mathrm{~mm}$ in diameter and $31.4 \mathrm{~cm}$ in height. The potting mix used was the Fafard 52 mix (Conrad Fafard, Inc.), which contains $\approx 60 \%$ pine bark along with Canadian sphagnum peat, perlite, vermiculite, dolomitic limestone, and gypsum; the reported $\mathrm{pH}$ is 5.5 to 6.5 .

Nitrogen was supplied with a granular controlled-release formulation $\left(\mathrm{MESA}^{\mathrm{TM}}\right.$; Lebanon Turf) containing $30 \% \mathrm{~N}(30 \mathrm{~N}-0 \mathrm{P}-$ $0 \mathrm{~K}$ ) and $12 \%$ sulfur. The fertilizer is a homogenous granule of approximately equal amounts of ammonium sulfate and methylene urea polymers.

Before potting, the seedlings were rootpruned to an approximate root length of 25 $\mathrm{cm}$. Seedlings were potted at root-collar depth on 19 May 2007 and placed in the greenhouse where they received various fertilization and irrigation treatments throughout the growing 
season (described subsequently) until 30 Sept. 2007. At that date, all plants were moved outdoors to a lath house for hardening. The lath house was covered with polyurethane throughout the winter to protect seedlings from extreme temperatures. On 15 Apr. 2008 (before budbreak), plants were moved back into the greenhouse for a second growing season.

Treatments. Three $\mathrm{N}$ rates were topdressed as a single yearly application at the beginning of each of the two growing seasons (6 May 2007 and 14 May 2008). Irrigation was manually applied during the growing season at rates of $386,257,122$, and $63 \mathrm{~mL} /$ pot/d (Monday to Friday) between $140 \mathrm{HR}$ and $1700 \mathrm{HR}$. Initial analysis showed that irrigation water contained $0.06 \mathrm{ppm}$ manganese, $16.3 \mathrm{ppm}$ magnesium, $68.4 \mathrm{ppm}$ calcium, and $0.02 \mathrm{ppm}$ potassium. Four irrigation treatments $(\mathrm{I} 1=386 \mathrm{~mL} / \mathrm{d}, \mathrm{I} 2=257 \mathrm{~mL} / \mathrm{d}, \mathrm{I} 3=$ $122 \mathrm{~mL} / \mathrm{d}$, and $\mathrm{I} 4=63 \mathrm{~mL} / \mathrm{d}$ ) were combined with three fertilization treatments $(\mathrm{F} 1=6 \mathrm{~g}$, $\mathrm{F} 2=12 \mathrm{~g}$, and $\mathrm{F} 3=18 \mathrm{~g}$ ) in a factorial arrangement. Each treatment had nine containers replicated three times for a total of 27 plants in each treatment and 324 plants for the entire experiment.

Growth characterization. Baseline tree height from the soil surface and stem diameter (root collar) was measured shortly after potting in May 2007 on all trees. Trees were remeasured at the end of the 2007 and 2008 seasons (11 Sept. 2007 and 26 Sept. 2008). Height and diameter growth were calculated as the difference between the final and initial measurements.

Ten trees were randomly selected and used determination of the initial root, stem, and foliar biomass in May 2007. At the end of the 2008 growing season (30 Sept. 2008), two random specimens were collected from each replicate (six plants total per treatment) to determine final biomass for each treatment. Biomass accumulation for stems, roots, and foliage were calculated as the difference between the final and initial biomass for each treatment.

Plant tissue sampling and analyses. Needles were collected for nutrient analyses at the end of the growing season in each year. Tissues harvested were oven dried at 60 to $65{ }^{\circ} \mathrm{C}$ and ground into a fine powder. Approximately $0.3 \mathrm{~g}$ of material was placed into the $75-\mathrm{mL}$ digestion tube and acid-digested with a mixture of sulfuric acid $(4.5 \mathrm{~mL})$ and hydrogen peroxide $(1.5 \mathrm{~mL})$. Samples were pre-digested for $2 \mathrm{~h}$ and placed into a block digester (AIM600 Block Digestion System) at $340 \pm 10{ }^{\circ} \mathrm{C}$ for heat digestion under a programmed temperature schedule.

Total $\mathrm{N}$ was determined as described by Christianson and Holt (1986). Aliquots from the digested solution were buffered and after dialysis chlorinated to form a chemical complex measured at $660 \mathrm{~nm}$ for total $\mathrm{N}$ on a SAN++ segmented flow analyzer (Skalar Inc., Atlanta, GA). The total phosphorous content determination was based on the ammonium heptamolybdate and potassium antimony (III) reaction that form under acidic environment an antimony-phospho-molybdate complex measured at $880 \mathrm{~nm}$ on the SAN++ segmented flow analyzer. Other macronutrients, including potassium $(\mathrm{K})$, calcium $(\mathrm{Ca})$, magnesium $(\mathrm{Mg})$, and manganese $(\mathrm{Mn})$, were determined by atomic absorption spectrometry (AAnalyst 400; Perkin Elmer).

Leachate collection and analysis. Leachates were collected from a subset of containers in each treatment (six in 2007 and three in 2008) using plastic trays placed under the containers. Water drained naturally into the collection trays during the week and was collected from the tray twice weekly. The two samples were then combined and their volume measured. An aliquot of $100 \mathrm{~mL}$ collected from each container was stored at $4{ }^{\circ} \mathrm{C}$ before analysis.

Stored samples were used for determination of the nutrient concentration. Aliquots $(15 \mathrm{~mL})$ used for total $\mathrm{N}$ and total phosphorous were persulfate $\left(\mathrm{K}_{2} \mathrm{SO}_{4}\right)$ digested according to Cabrera and Beare (1993). A second aliquot $(30 \mathrm{~mL})$ was filtered $(70-\mu \mathrm{m}$ filter paper) and analyzed for $\mathrm{K}, \mathrm{Ca}, \mathrm{Mg}$, and $\mathrm{Mn}$ using the AAnalyst 400 atomic absorption spectrometer. The total mass $(\mathrm{mg})$ of each nutrient ion leached per week was calculated from the total volume leached and the aliquot ion concentration for each element.

Data analysis. Resource use efficiency parameters were calculated as described by Sheriff et al. (1995), given by:

ANUE: Assimilatory nutrient use efficiency (rate of carbon assimilation, or foliar biomass production per unit of foliar $\mathrm{N}$ ).

NUE: Whole plant nutrient use efficiency in grams of biomass/g of $\mathrm{N}$ per year.

N/RW: Index of N availability (foliar N per unit root weight).

RWR: Root weight ratio (grams of root/g of total biomass).

Growth attributes, biomass, and nutrient content data were first tested for homogeneity of variance and normality. A general factorial model combining main effects and interaction as described in Eq. (1) was used.

$$
\mathrm{Y}=\beta_{0}+\beta_{1} A+\beta_{2} \mathrm{~B}+\beta_{3} \mathrm{AB}
$$

where $\beta_{0}$ is the model intercept, $\beta_{1}$ and $\beta_{2}$ are coefficients associated with factor $\mathrm{A}$ and $\mathrm{B}$, and $\beta_{3}$ is the coefficient associated with the combination of factors $\mathrm{A}$ and $\mathrm{B}$, representing the interaction in the model. Analysis of variance was performed for a $3 \times 4$ randomized design with three replications on all response variables using the linear model described previously. A level of significance of $\alpha=0.05$ was used for inferring any statistical significance. For growth, when the model was significant, the least significant difference method with a Bonferroni correction at $P \leq 0.05$ was used to make pairwise comparisons between responses. Linear regression analysis was used to evaluate the quantitative impact of the two main effects (irrigation and $\mathrm{N}$ applications) on growth, biomass, and organs nutrient content parameters. The GLM procedure for repeated measures $(P \leq 0.05)$ was used to analyze the leachate nutrient concentrations. All statistical analyses were performed using Systat 12 statistical software (Systat Software, Inc., Chicago, IL).

\section{Results}

Growth response. Two years cumulative growth data indicate a significant effect of irrigation and fertilization on height growth, but root-collar diameter was affected by irrigation and not by fertilization (Table 1). There was no interaction between the irrigation and fertilization on neither height nor root-collar diameter. Irrigation increased height growth by $12 \%$ to $35 \%$ (from lowest to highest irrigation), whereas diameter growth increased up to $54 \%$ (from lowest to highest irrigation).

Total biomass generally increased with irrigation treatments from $40 \mathrm{~g}$ to $110 \mathrm{~g} /$ tree

Table 1. Growth and biomass accumulation of containerized fraser fir transplants in response to irrigation and fertilization ( 2 years accumulated)

\begin{tabular}{|c|c|c|c|c|c|c|}
\hline \multirow[b]{2}{*}{ Treatments } & \multirow{2}{*}{$\begin{array}{l}\text { Ht growth } \\
(\mathrm{cm})\end{array}$} & \multirow{2}{*}{$\begin{array}{l}\text { Diam growth } \\
(\mathrm{mm})\end{array}$} & \multicolumn{3}{|c|}{ Dry wt } & \multirow[b]{2}{*}{ Shoot/root } \\
\hline & & & Stem (g) & Roots (g) & Needles (g) & \\
\hline \multicolumn{7}{|l|}{ Irrigation $^{z}$} \\
\hline Level 1 & $16.3(0.8)^{x}$ & $5.9(0.5)$ & $49.0(11.6)$ & $36.0(4.4)$ & $23.0(3.1)$ & $1.9(0.5)$ \\
\hline Level 2 & $14.1(1.2)$ & $6.0(0.2)$ & $47.6(13.9)$ & $35.4(2.6)$ & $30.8(1.3)$ & $2.1(0.2)$ \\
\hline Level 3 & $12.2(1.2)$ & $4.6(0.4)$ & $23.5(2.7)$ & $27.7(0.9)$ & $16.4(1.2)$ & $1.4(0.1)$ \\
\hline Level 4 & $9.4(0.8)$ & $3.8(0.1)$ & $13.1(3.8)$ & $13.1(1.6)$ & $11.1(1.5)$ & $1.8(0.2)$ \\
\hline Significance & $* * r^{2}=0.80$ & $* * * r^{2}=0.85$ & $* * r^{2}=0.71$ & $* * r^{2}=0.80$ & $* r^{2}=0.68$ & NS \\
\hline \multicolumn{7}{|l|}{ Nitrogen ${ }^{y}$} \\
\hline Level 1 & $11.0(1.1)$ & $4.6(0.5)$ & $20.1(2.9)$ & $25.5(3.5)$ & $19.6(3.7)$ & $1.6(0.1)$ \\
\hline Level 2 & $12.0(1.6)$ & $5.1(0.5)$ & $29.0(14.2)$ & $27.9(6.6)$ & $19.3(5.4)$ & $2.1(0.4)$ \\
\hline Level 3 & $15.2(1.8)$ & $5.6(0.6)$ & 40.9 (10.6) & $30.9(6.3)$ & $22.2(4.2)$ & $1.9(0.2)$ \\
\hline Significance & NS & NS & NS & NS & NS & NS \\
\hline
\end{tabular}

${ }^{\mathrm{z}}$ Irrigation levels $1,2,3$, and $4=386,257,122$, and $63 \mathrm{~mL}$ per pot per week, respectively.

${ }^{y}$ Nitrogen levels 1,2 , and $3=6,12$, and 18 g per pot, respectively.

${ }^{\mathrm{x}}$ Numbers in parentheses are SES of the arithmetic mean.

Height and diameter growth and biomass data were analyzed for main effect by simple regression analysis and analysis of variance at $P \leq 0.05$.

$\mathrm{NS}, *, * *, * * *$ Nonsignificant, or significant at $P \leq 0.05,0.01$, or 0.001 , respectively. 
depending on the treatment. Higher fertilization treatments (12 g and $18 \mathrm{~g}$ ) generally produced more biomass, especially when combined with high irrigation treatments. The partition of the accumulated biomass indicates that needle biomass accumulation did not increase with higher irrigation and fertilization treatments, but root and stem biomass accumulation were generally positively affected by both factors (Table 1). Irrigation significantly affected only root biomass production, whereas fertilization affected stem, root, and foliage biomass. There was no interaction between the two factors for any of these three organs.

Foliar nutrient concentration. Foliar N concentration generally increased as the applied amount of irrigation decreased with a more pronounced effect in 2007 compared with 2008 (Fig. 1). Increased irrigation reduced the foliar $\mathrm{N}$ concentration in 2007 ( $P \leq$ $0.00)$ but not in $2008(P \leq 0.17)$. Increased fertilization increased the foliar $\mathrm{N}$ concentration in both $2007(P \leq 0.01)$ and $2008(P \leq$ $0.00)$. The phosphorus $(\mathrm{P})$ concentration was unaffected by either irrigation or fertilization. The N/P ratio varied from 9.8 to 15.5 depending on the treatment. Ratios above 10 are considered adequate for foliar $\mathrm{N}$ and $\mathrm{P}$ nutrition (Landis, 1989).

Foliar Ca concentration slightly increased with irrigation in both 2007 and 2008 (Fig. 2) with changes statistically significant in both years ( $P \leq 0.05$ and $P \leq 0.00$, respectively). Foliar $\mathrm{K}, \mathrm{Mg}$, and $\mathrm{Mn}$ were unaffected by increased irrigation treatments (Fig. 2).

Nitrogen accumulation. Needle and stem $\mathrm{N}$ content were unaffected by irrigation but were significantly affected by fertilization with no interaction (Table 2). Root and total plant $\mathrm{N}$ were significantly affected by both irrigation and fertilization. Higher irrigation treatment resulted in enhanced $\mathrm{N}$ use efficiency compared with lower water treatments (Table 2).

Nutrient leaching. The computation of the cumulated volume leached indicated a leaching fraction of $3.0 \%$ to $23.8 \%$ depending on the irrigation treatment (Table 3 ). Treatments at $386 \mathrm{~mL} /$ pot produced average leaching fractions of $21.7 \%$ (2007) and $11.0 \%$ (2008), whereas $257-\mathrm{mL} /$ pot treatments leached $6.5 \%(2007)$ and $9.6 \%$ (2008). No leachate was collected in either year on plants treated with $63 \mathrm{~mL} /$ pot or $122 \mathrm{~mL} /$ pot in either year. The leaching fractions correspond to $4.5 \%$ (2007) and 4.0\% (2008) total $\mathrm{N}$ leached for the $386-\mathrm{mL} /$ pot treatments and 3.1\% (2007) and $2.0 \%(2008)$ total $\mathrm{N}$ leached for the 257 $\mathrm{mL} /$ pot treatments (Table 3 ). The repeatedmeasures mixed model at $95 \%$ confidence interval indicated that the difference in $\mathrm{N}$ concentration in weekly leachates collected was not significant in $2007(P=0.49)$ but was highly significant in $2008(P=0.00)$.

The total cumulative leaching for $\mathrm{Ca}, \mathrm{K}$, and $\mathrm{Mg}$ (Fig. 3), indicates no statistical difference in total $\mathrm{Ca}$ or total $\mathrm{K}$. The total $\mathrm{Mg}$ leached was significantly affected by irrigation with the highest irrigation treatment $(386 \mathrm{~mL} /$ pot $)$ exhibiting much higher cumulated total $\mathrm{Mg}$ leached in both 2007 $(P \leq 0.00)$ and $2008(P \leq 0.01)$.

The Mn and orthophosphate concentrations in leachates were negligible and thus are not included in the data reported.
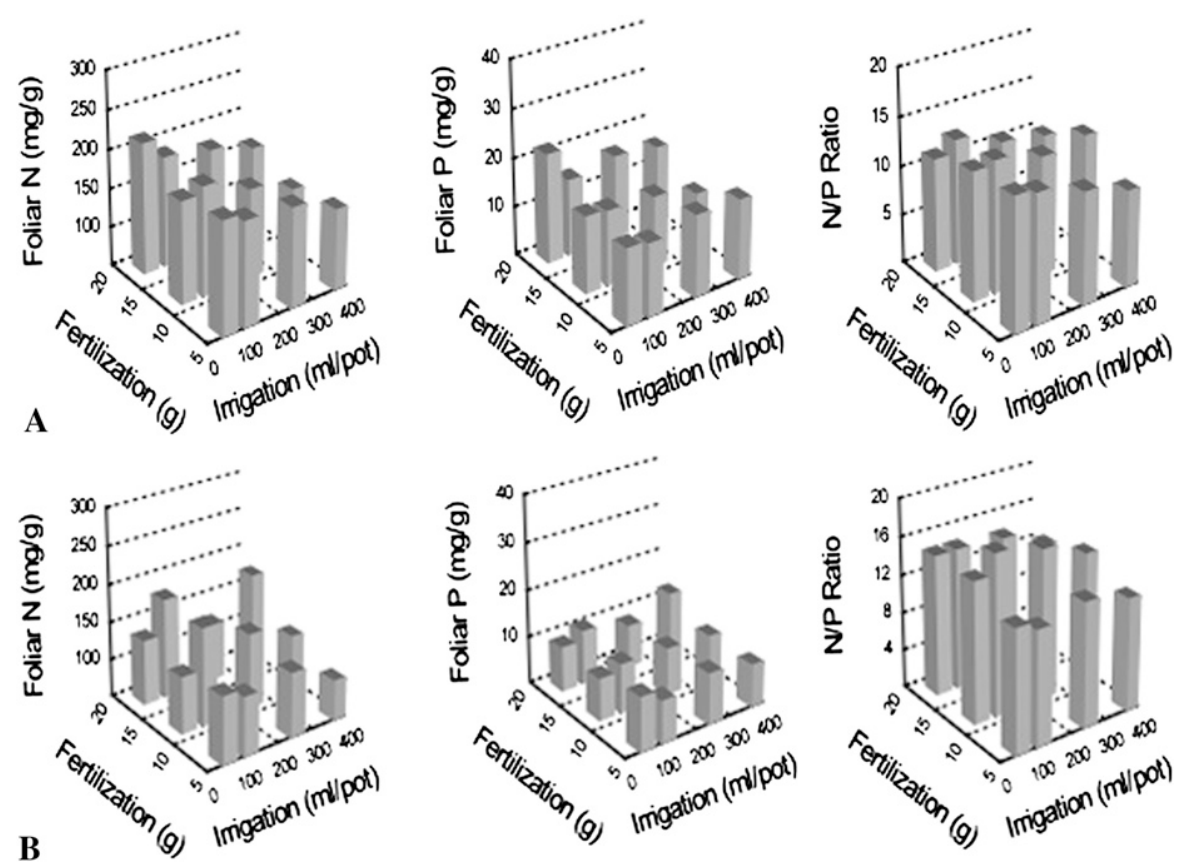

Fig. 1. Change in foliar nitrogen $(\mathrm{N})$ and phosphorous $(\mathrm{P})$ concentrations and N/P ratio as affected by irrigation and fertilization in 2007 on the top three panels $(\mathbf{A})$ and 2008 in the bottom three panels $(\mathbf{B})$. Foliar N content was affected by irrigation in $2007(P=0.00)$ but not in $2008(P=0.18)$. The $\mathrm{N}$ content was significant affected by fertilization in both $2007(P=0.01)$ and $2008(P=0.01)$. Irrigation: $\mathrm{I} 1=386$ $\mathrm{mL}, \mathrm{I} 2=257 \mathrm{~mL}, \mathrm{I} 3=122 \mathrm{~mL}, \mathrm{I} 4=63 \mathrm{~mL}$; fertilization F1 = $6 \mathrm{~g}, \mathrm{~F} 2=12 \mathrm{~g}, \mathrm{~F} 3=18 \mathrm{~g}$.
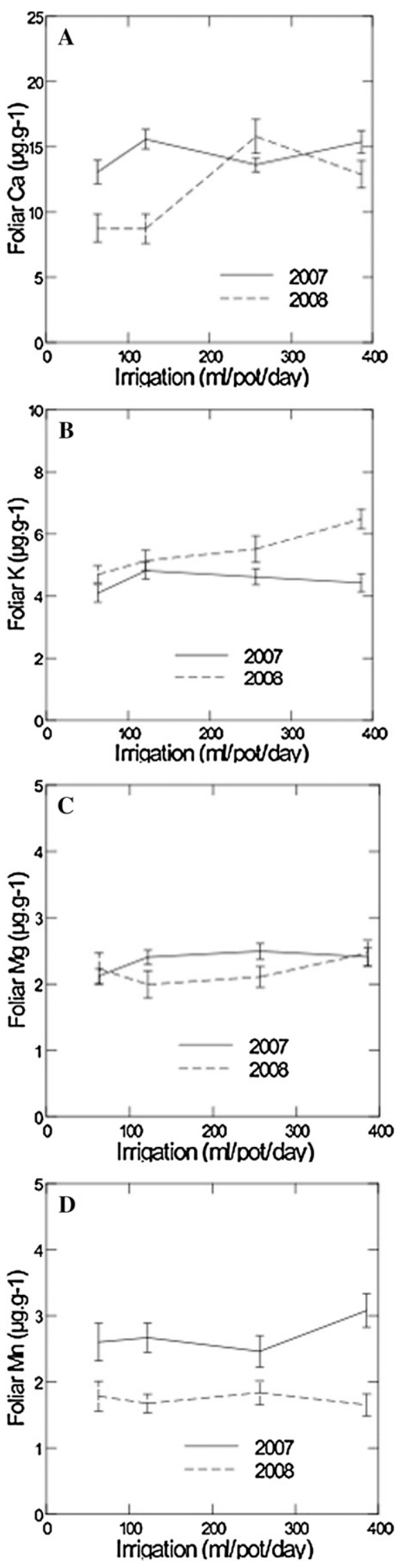

Fig. 2. Change in foliar calcium (Ca) (A), potassium $(\mathrm{K})(\mathbf{B})$, magnesium $(\mathrm{Mg})(\mathbf{C})$, and manganese (Mn) (D) as affected by irrigation treatment in 2007 (continuous lines) and 2008 (discontinued lines). Ca was the only element significantly affected by irrigation treatments. 
Table 2. Plant nitrogen $(\mathrm{N})$ content partitioning in response to irrigation and fertilization $(\mathrm{mg}$ of $\mathrm{N})$.

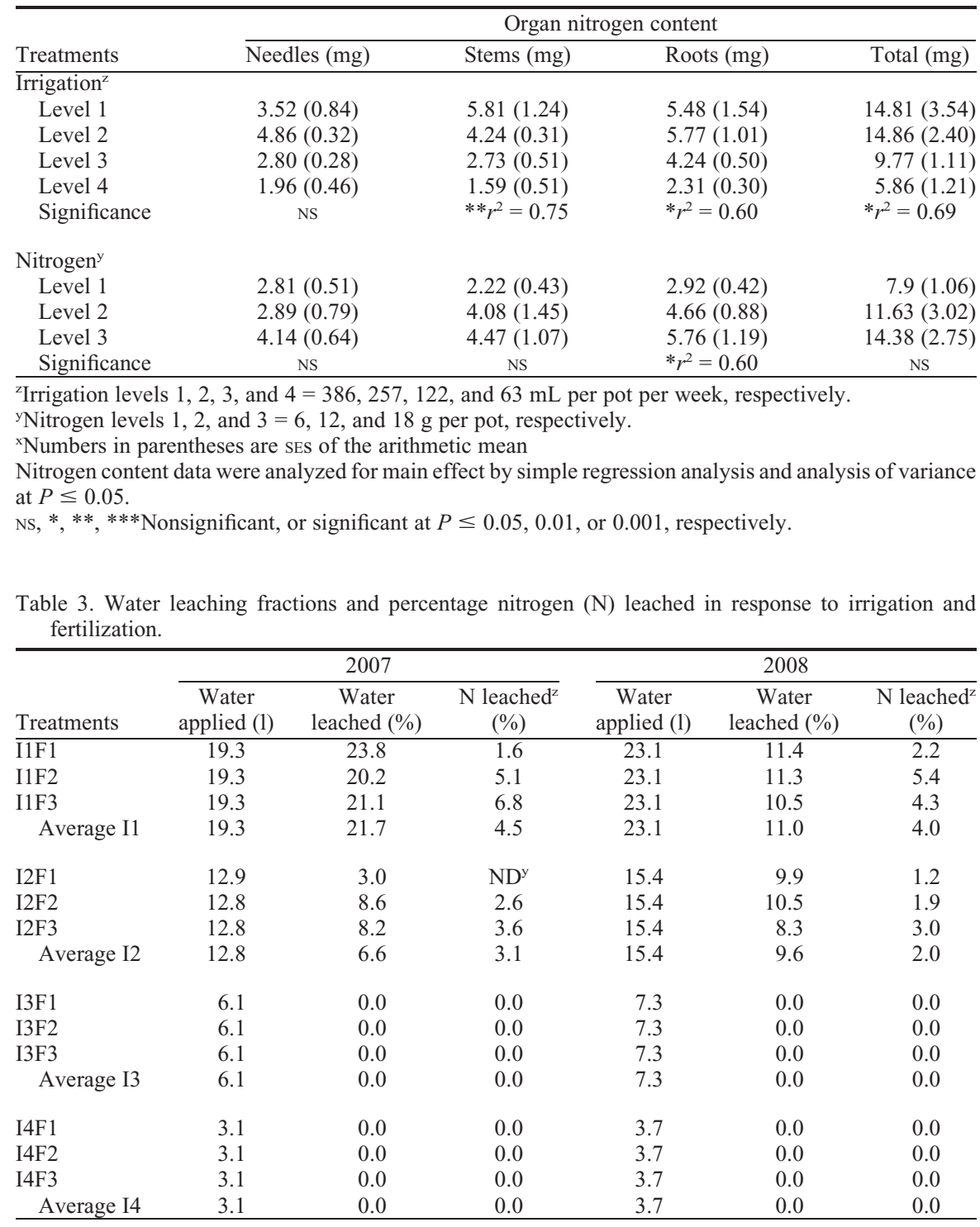

Irrigation: $\mathrm{I} 1=386 \mathrm{~mL}, \mathrm{I} 2=257 \mathrm{~mL}, \mathrm{I} 3=122 \mathrm{~mL}, \mathrm{I} 4=63 \mathrm{~mL}$; fertilization $\mathrm{F} 1=6 \mathrm{~g}, \mathrm{~F} 2=12 \mathrm{~g}, \mathrm{~F} 3=18 \mathrm{~g}$. ${ }^{z}$ The effect of irrigation on the $\mathrm{N}$ concentration in leachates was analyzed by the repeated-measures analysis of variance procedures. The N concentration in leachates was not significant in $2007(P=0.5)$ and highly significant in $2008(P=0.00)$.

${ }^{\mathrm{ND}}=$ no data.

Resource use efficiency. Assimilatory nitrogen use efficiency (ANUE), and $\mathrm{N}$ use efficiency generally increased with irrigation amounts (Table 3 ). The index of $\mathrm{N}$ availability per unit foliage $(\mathrm{N} / \mathrm{RW})$ was the lowest at the highest irrigation treatment and highest at the lowest treatment. Root weight values were similar for all irrigation treatments (Table 3).

\section{Discussion}

Growth. Both water and N were limiting for height growth, but there was no significant interaction between the two (Table 1). Stem diameter growth responded positively to irrigation but not fertilization. Biomass accumulation also increased with irrigation. These conclusions agree with previous studies related to growth, volume, and biomass production as related to fertilization and
(Fig. 1) were generally within the range of nutrient sufficiency for containerized conifers (Landis, 1989). High water treatments negatively affected foliar $\mathrm{N}$ concentration, but increased fertilization positively affected foliar N. Lower growth and biomass accumulations obtained with low water treatments should normally result in lower demand for nutrient elements (Clarkson, 1985), which were possibly met by lower nutrient availability and uptake under low fertilization and moisture treatments. This can explain why sufficiency levels were observed even in low fertility and low moisture treatments. The marginal effect of irrigation and lack of interaction between foliar $\mathrm{N}$ and $\mathrm{P}$ and irrigation may have been caused by the elevated volumes of leaching in high irrigation treatments. Increased resource availability also positively affected foliar Ca content but not foliar $\mathrm{K}, \mathrm{Mg}$, or $\mathrm{Mn}$ contents (Fig. 2). The reason for the significant effect on foliar $\mathrm{Ca}$ needs to be further investigated because Berger (1994) did not observe any change in $\mathrm{Ca}, \mathrm{K}$, or $\mathrm{Mg}$ concentration in xylem sap after mild or severe drought cycles.

The response to the addition of water and nutrients can be variable and depends on seasonal site water balance and initial soil fertility (Trichet et al., 2008). Therefore, increased water addition through irrigation is likely to leach mobile nutrients such as nitrates below the root zone. The strong foliar nutrient concentration response to fertilization suggests that $\mathrm{N}$ addition is a strong determining factor for early development of this species.

Plant nitrogen accumulation and resource use efficiency. The lower foliar $\mathrm{N}$ concentration in higher water treatments was opposite the increased growth response, indicating higher $\mathrm{N}$ use efficiency (NUE) and ANUE in high irrigation treatments (Table 4). This is the result of higher efficiency in carbon assimilation that caused an increase in the net primary productivity in plants under high irrigation treatment. For the lowest fertilizer and irrigation treatments, low assimilation levels resulted in reduced biomass production. However, because foliar concentration was used in the calculation of ANUE, it is necessary to take into account the resource partitioning between assimilatory and nonassimilatory activities such as biochemical processes, structure, and storage (Margolis and Brand, 1990; Sheriff et al., 1995).

Evaluation of the partitioning efficiency did not show a clear improvement of the root weight ratio in plants receiving high irrigation and water treatments (Table 4). However, the index of $\mathrm{N}$ availability in the foliage per unit of root $(\mathrm{N} / \mathrm{RW})$ to supply suggests enhanced $\mathrm{N}$ availability for plants receiving lower irrigation treatments. This implies that under water stress conditions, the decrease in assimilation in plants is somewhat buffered by the increase in the relative ability of plants to allocate resources to roots development. This is in agreement with previous studies suggesting that efficiencies of use water and foliar $\mathrm{N}$ in assimilating carbon 

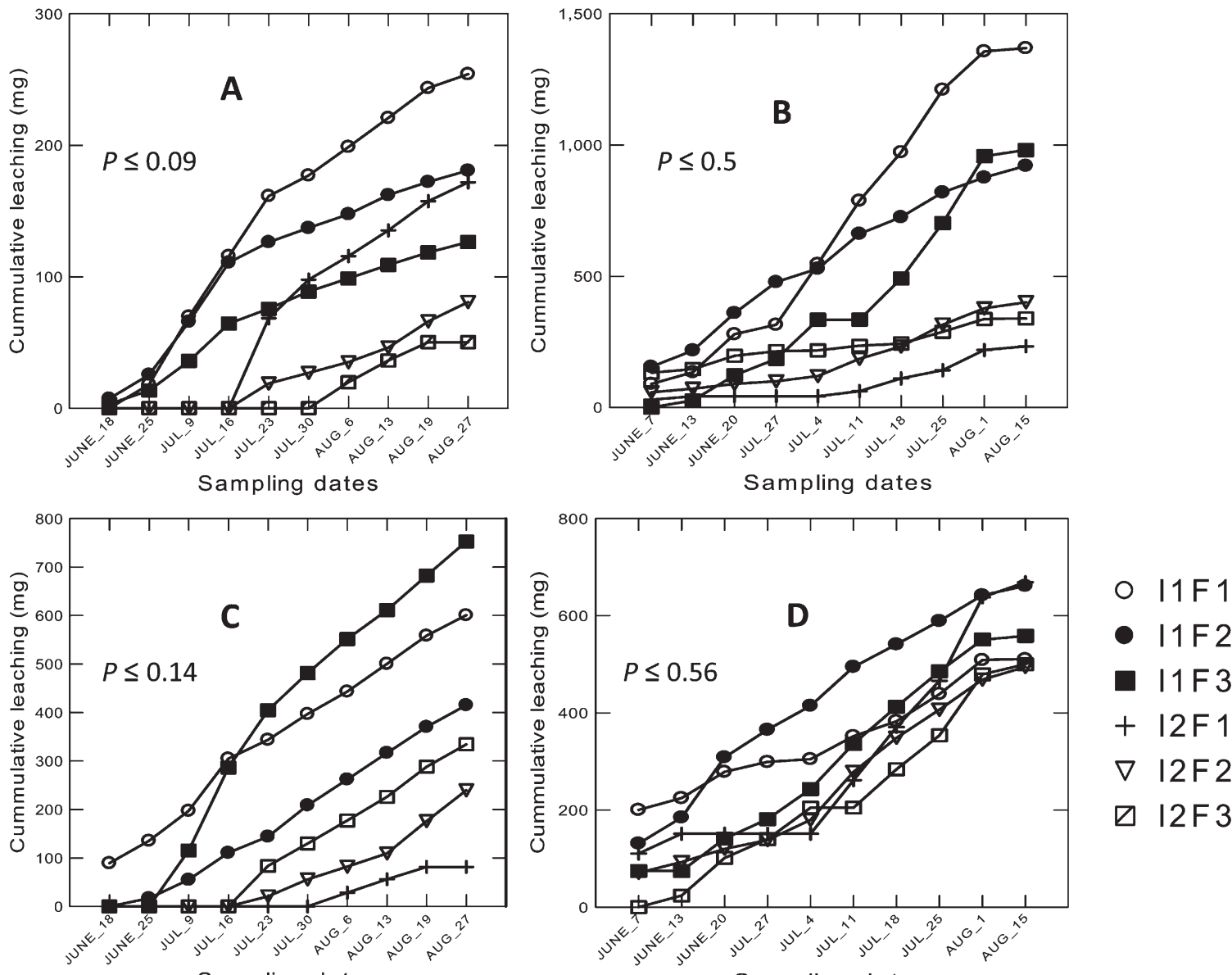

Sampling dates
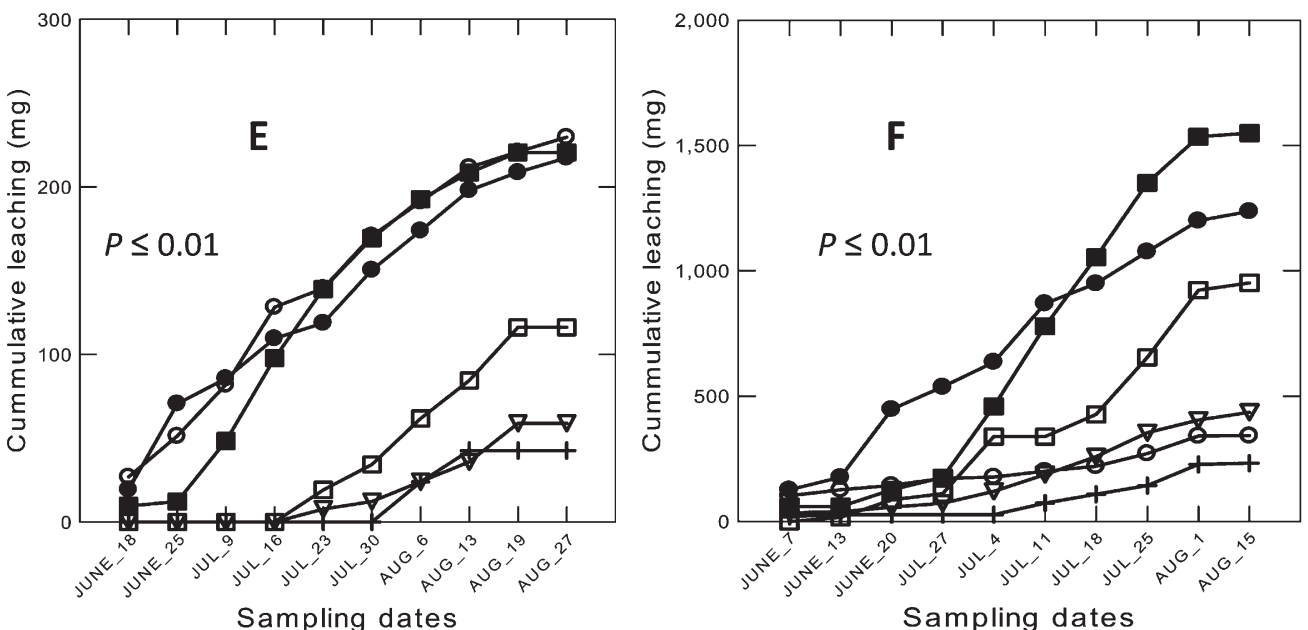

Fig. 3. Cumulative calcium (A-B), potassium (C-D), and magnesium (E-F) leached in response to irrigation treatments in 2007 (left panels) and 2008 (right panels).

have opposing constraints such that if they vary with experimental treatments or species, they are often negatively correlated (Farquhar and Kirschbqum, 1985).

\section{Conclusion}

This study investigated the growth, nutrient concentration and content, and NUE of plants under varying irrigation and fertilization treatments. Height and stem diameter growth were increased by irrigation treatments, possibly as a result of increased photosynthesis and subsequent carbohydrate production resulting from improved stomatal response in low water stress conditions in trees under high irrigation. Increases in biomass were caused by a resource partitioning process favoring root growth.

The resource use efficiency analysis suggests that under low water stress, Abies fraseri had a higher efficiency in carbon accumula- tion that caused an increased in net primary productivity. Under water stress conditions, the decrease in assimilation can be buffered by an increase in the plant's abilities to provide $\mathrm{N}$ and other nutrients to various organs. The improved resource use efficiency resulting from irrigation can be attributed to one or any combination of factors, including improvements in the photosynthetic ability; decrease in stomatal limitations; changes in resource allocation in favor of the stem; or 
Table 4. Resource use efficiency parameters of fraser fir transplants grown in containers as affected by irrigation and fertilization.

\begin{tabular}{|c|c|c|c|c|}
\hline & ANUE $(g / \mu \mathrm{g} / \mathrm{g})$ & NUE (g/g/yr) & N/RW (mg/g) & RWR (g/g) \\
\hline$\overline{\mathrm{I} 1 \mathrm{~F} 1}$ & $0.15 \pm 0.1$ & $32.4 \pm 0.5$ & $84.0 \pm 2.1$ & $0.38 \pm 0.01$ \\
\hline I1F2 & $0.14 \pm 0.1$ & $48.7 \pm 1.4$ & $81.1 \pm 2.5$ & $0.29 \pm 0.03$ \\
\hline I1F3 & $0.16 \pm 0.1$ & $36.7 \pm 1.6$ & $118.5 \pm 2.0$ & $0.34 \pm 0.01$ \\
\hline Average I1 & $0.15 \pm 0.1$ & $39.3 \pm 1.2$ & $94.5 \pm 2.2$ & $0.34 \pm 0.02$ \\
\hline I2F1 & $0.20 \pm 0.1$ & $31.8 \pm 0.9$ & $140.2 \pm 3.6$ & $0.38 \pm 0.02$ \\
\hline $\mathrm{I} 2 \mathrm{~F} 2$ & $0.22 \pm 0.2$ & $45.8 \pm 1.5$ & $129.4 \pm 1.9$ & $0.29 \pm 0.0$ \\
\hline $\mathrm{I} 2 \mathrm{~F} 3$ & $0.16 \pm 0.1$ & $25.5 \pm 0.8$ & $143.0 \pm 1.2$ & $0.40 \pm 0.0$ \\
\hline Average I2 & $0.19 \pm 0.1$ & $34.4 \pm 1.1$ & $137.5 \pm 2.2$ & $0.36 \pm 0.0$ \\
\hline I3F1 & $0.12 \pm 0.1$ & $26.7 \pm 1.0$ & $99.2 \pm 1.6$ & $0.43 \pm 0$. \\
\hline I3F2 & $0.09 \pm 0.1$ & $21.4 \pm 0.7$ & $88.5 \pm 1.5$ & $0.41 \pm 0.0$ \\
\hline I3F3 & $0.08 \pm 0.1$ & $22.0 \pm 0.8$ & $114.4 \pm 1.8$ & $0.39 \pm 0.0$ \\
\hline Average I3 & $0.10 \pm 0.1$ & $23.3 \pm 0.8$ & $100.7 \pm 1.6$ & $0.41 \pm 0.0$ \\
\hline I4F1 & $0.07 \pm 0.1$ & $15.5 \pm 0.9$ & $121.5 \pm 1.7$ & $0.38 \pm 0.0$ \\
\hline I4F2 & $0.05 \pm 0.1$ & $7.8 \pm 0.8$ & $127.1 \pm 2.1$ & $0.39 \pm 0.0$ \\
\hline I4F3 & $0.07 \pm 0.1$ & $12.8 \pm 1.9$ & $195.4 \pm 1.7$ & $0.31 \pm 0.0$ \\
\hline Average I4 & $0.06 \pm 0.1$ & $12.0 \pm 1.2$ & $148.0 \pm 1.8$ & $0.36 \pm 0.0$ \\
\hline
\end{tabular}

increases in the ratio of photosynthesis to respiration. Further physiological studies are underway to confirm these hypotheses.

\section{Literature Cited}

Alam, S.M. 1999. Nutrient uptake by plants under stress conditions, p. 285-313. In: Pessarakli, M. (ed.). Handbook of plant and crop stress. Marcel Dekker, New York, NY.

Albaugh, T.J., H.L. Allen, and T.R. Fox. 2008. Nutrient uptake in Pinus taeda. Tree Physiol. 28:1083-1098.

Barrett, N.M. and A.W. Naylor. 1966. Amino acids and protein metabolism in Bermuda grass during water stress. Plant Physiol. 41:1222-1245.

Beck, D.E. 1990. Silvics of North America: Abies fraseri (Pursh) Poir. 2 Aug. 2007. <http://www. na.fs.fed.us/spfo/pubs/silvics_manual/Volume_1/ abies/fraseri.htm>.

Berger, A., R. Oren, and E.D. Schulze. 1994. Element concentrations in the xylem sap of Picea abies (L.) Karst. Seedlings extracted by various methods under different environmental conditions. Tree Physiology 14:111-128.

Cabrera, M.L. and M.H. Beare. 1993. Alkaline persulfate oxidation for determining total nitrogen in microbial biomass extracts. Soil Sci. Soc. Amer. J. 57:1007-1012.

Christianson, C.B. and L.S. Holt. 1986. Rapid digestion procedure for the determination of total nitrogen and Nitrogen-15 content of soils. Soil Sci. Soc. Amer. J. 53:1917-1920.

Clarkson, D.T. 1985. Factors affecting mineral nutrient acquisition by plants. Annual Review of Plant Physiology and Plant Molecular Biology 36:77-115.

Coleman, M.D., J.G. Isebrands, D.N. Tolsted, and V.R. Tolbert. 2004. Comparing soil carbon of short rotation poplar plantations with agricultural crops and woodlots in North Central United States. Environmental Mgt. 33:299-308.

Farquhar, G.D. and M.U.F. Kirschbqum. 1985. Environmental constraints on carbon assimilation, p. 87-97. In: Jeffcoat, B., A.F. Hawkis, and A.D. Stead (eds.). Regulation of sources and sinks in crop plants. British Plant Growth Regulator Group Monograph No. 12, Long Ashton, Bristol, UK.

Gerakis, P.A., F.P. Geurrero, and W.A. Williams. 1975. Growth, water relations and nutrition of three grassland annuals affected by drought. J. Appl. Ecol. 12:125-149.

Grindley, D.J.C. 1997. Towards an explanation of crop nitrogen demand based on the optimal leaf nitrogen per unit lead area. J. Agr. Sci. Camb. 128:377-396.

Hinesley, L.E., L.E. Nelson, and G.L. Switzer. 1991. Weight and nutrient content of litter during secondary succession on well drained uplands of the East Gulf Coastal Plain in Mississippi. Can. J. For. Res. 21:848-857.
Jamieson, P.D., R.F. Zyskowski, F.Y. Li, and M.A. Semenov. 2009. Water and nitrogen uptake and responses in models of wheat, potatoes, and maize, p. 127-145. In: Ma, L., L.R. Ahuja, and T.W. Bruulsema (eds.). Quantifying and understanding plant nitrogen uptake for systems modeling. Taylor and Francis Group, Boca Raton, FL.

Jenne, E.A., H.F. Rhoades, C.H. Yien, and O.W. Howe. 1958. Change in nutrient element accumulation by corn with depletion of soil moisture. Agron. J. 50:71.

Landis, T.D. 1989. Mineral nutrients and fertilization, p. 1-67. In: Landis, T.D., R.W. Tinus, S.E. McDonald and J.P. Barnett (eds.). The container tree nursery manual, seedlings nutrition and irrigation. Vol. 4. U.S. Dept. Agr. Forest Serv. Agr. Hdbk. 674, Washington, DC.

Levitt, J. 1980. Responses of plants to environmental stresses. 2nd Ed. Academic Press, New York.

Margolis, H.A. and D.G. Brand. 1990. An ecophysiological basis for understanding plantation establishment. Can. J. For. Res. 20:375390.

Nilsson, U. and G. Orlander. 2003. Response of newly planted Norway spruce seedlings to fertilization, irrigation and herbicide treatments. Ann. For. Sci. 60:637-643.

Nzokou, P. and L.A. Leefers. 2007. Costs and returns in Michigan Christmas tree production. MSUE Extension Bulletin 2999. Michigan State Univ., East Lansing, MI.

Sheriff, D.W., H.A. Margolis, M.R. Kaufmann, and P.B. Reich. 1995. Resource use efficiency, p. 143-178. In: Smith, W.K. and T.M. Hickley (eds.). Resource physiology of conifers. Academic Press, San Diego, CA.

Singh, T.N., L.G. Paleg, and D. Aspinall. 1973. Stress metabolism and growth in barley during water stress. Aust. J. Biol. Sci. 26:45-59.

Snowdon, P. and M.L. Benson. 1992. Effect of the combination of irrigation and fertilization on the growth and above-ground biomass production of Pinus radiata. For. Ecol. Mgt. 52:87116.

Tanguilig, V.C., E.B. Yambao, J.C.O. Toole, and S.K. DeDatta. 1987. Water stress effects on leaf elongation, leaf water potential, transpiration, and nutrient uptake of rice, maize, and soybean. Plant Soil 103:155-170.

Trichet, P., D. Loustau, C. Lambrot, and S. Linder. 2008. Manipulating nutrient and water availability in a maritime pine plantation: Effect on growth, production and biomass allocation at canopy closure. Ann. For. Sci. 65:814 826.

Turner, N.C. and J.E. Begg. 1981. Plant-water relations and adaptation to stress. Plant Soil 58:97-101. 